NBER WORKING PAPER SERIES

\title{
POLICY WATCH: CHALLENGES FOR TERRORISM RISK INSURANCE IN THE UNITED STATES
}

\author{
Howard Kunreuther \\ Erwann Michel-Kerjan \\ Working Paper 10870 \\ http://www.nber.org/papers/w10870
}

\author{
NATIONAL BUREAU OF ECONOMIC RESEARCH \\ 1050 Massachusetts Avenue \\ Cambridge, MA 02138 \\ October 2004
}

\begin{abstract}
Forthcoming in the Journal of Economic Perspectives. We are grateful to James Ament, Debra Ballen, Jeffrey Brown, Dan Conway, Christophe Courbage, David Cummins, Neil Doherty, William Dove, Martin Feldstein, Rich Franklin, Christian Gollier, Anne Gron, Patricia Grossi, Geoffrey Heal, Carl Hedde, Claude Henry, James Hines, Dwight Jaffee, Ken Jenkins, Maurice Kilavuka, Paul Kleindorfer, Patrick Lagadec, James Macdonald, Don Mango, Linda Moeller, David Moss, Frank Nutter, Paul O'Connell, Mike O’Malley, Chandu Patel, Burkhard Pedell, Beverly Porter, Thomas Russell, Todd Sandler, Jack Seaquist, Jason Schupp, Stephen Shore, Kent Smetters, Greg Stern, Craig Tillman, François Vilnet, Michael Waldman, Gordon Woo and especially to Timothy Taylor for discussions and valuable comments on earlier drafts of this paper. We also appreciated meaningful discussions on related issues with workshop participants at the National Bureau of Economics Research (NBER) Insurance Group, Lawrence Livermore National Laboratory, Brookings-Wharton Conference on Financial Institutions, Harvard University's Kennedy School of Government, Wharton Managing and Financing Extreme Events meetings and participants at the World Economic Forum in Davos as well as with members of the U.S. General Accounting Office (now the U.S. Government Accountability Office), U.S. Treasury, American Insurance Association, American Reinsurance Association, Geneva Association for the Study of Insurance Economics, GAREAT, Extremus, and the OECD Task Force on Terrorism Insurance on which we both serve. The authors wish to thank Lockheed Martin, Radiant Trust, the Institut Veolia Environnement and the Wharton Risk Management and Decision Processes Center for financial support of this project. The views expressed herein are those of the author(s) and not necessarily those of the National Bureau of Economic Research.
\end{abstract}

(C2004 by Howard Kunreuther and Erwan Michel-Kerjan. All rights reserved. Short sections of text, not to exceed two paragraphs, may be quoted without explicit permission provided that full credit, including () notice, is given to the source. 
Policy Watch: Challenges for Terrorism Risk Insurance in the United States Howard Kunreuther and Erwan Michel-Kerjan

NBER Working Paper No. 10870

October 2004

JEL No. H56, G22, G28

\begin{abstract}
$\underline{\text { ABSTRACT }}$
This paper examines the role that insurance has played in dealing with terrorism before and after September 11, 2001, by focusing on the distinctive challenges associated with terrorism as a catastrophic risk. The Terrorism Risk Insurance Act of 2002 (TRIA) was passed by the U.S. Congress in November 2002, establishing a national terrorism insurance program that provides up to $\$ 100$ billion commercial coverage with a specific but temporary risk-sharing arrangement between the federal government and insurers. TRIA's three-year term ends December 31, 2005, so Congress soon has to determine whether it should be renewed, whether an alternative terrorism insurance program should be substituted for it, or whether insurance coverage is left solely in the hands of the private sector. As input into this process, the paper examines several alternatives and scenarios, and discusses their potential to create a sustainable terrorism insurance program in the Unites States.

Howard Kunreuther

Operations and Information Management

The Wharton School

University of Pennsylvania

Philadelphia, PA 19104-6366

and NBER

kunreuther@wharton.upenn.edu

Erwann Michel-Kerjan

The Wharton School

University of Pennsylvania

Philadelphia, PA 19104-6366

erwannmk@wharton.upenn.edu
\end{abstract}




\section{Introduction}

The terrorist attacks on September 11, 2001 against the United States raise a fundamental question about the responsibilities of the public and private sectors in reducing the risks of terrorist attacks and in providing adequate financial protection to victims of catastrophes. As defined by the White House (2002, p. 2), homeland security is "the concerted effort to prevent attacks, reduce America's vulnerability to terrorism, and minimize the damage and recover from attacks that do occur."

Although numerous efforts have been undertaken during the last three years to prevent new terrorist attacks on U.S. soil, the economic impact of another mega attack has to be seriously considered. More specifically, who should pay for future losses so as to assure business and social continuity should the terrorists be successful? This paper examines the role that insurance has played in dealing with terrorism before and after September 11, 2001. It then evaluates alternative terrorism insurance programs for the future, given that the U.S. Congress must soon decide whether to renew the Terrorism Risk Insurance Act (TRIA) that was passed in November 2002.

\section{Terrorism Insurance Before and After 9/11}

Even after the terrorist attack on the World Trade Center in 1993 and the Oklahoma City bombing in 1995, insurers in the United States did not view either international or domestic terrorism as a risk that should be explicitly considered when pricing their commercial insurance

policy, principally because losses from terrorism had historically been small and, to a large degree, uncorrelated. Thus, prior to September 11, 2001, terrorism coverage in the United States was an unnamed peril covered in most standard all-risk commercial and homeowners' policies covering damage to property and contents. 
The terrorist attacks of September 11, 2001, killed over 3,000 people from over 90 countries and inflicted insured losses currently estimated at $\$ 32.5$ billion that was shared by nearly 150 insurers and reinsurers worldwide. These attacks were the most costly event in the history of insurance, inflicting insured losses 1.5 times higher that of Hurricane Andrew in 1992, the previous record-holder. Commercial property, business interruption, workers' compensation, life, health, airline liability, and general liability insurance lines each paid out claims in the billions of dollars (Hartwig, 2004). ${ }^{2}$

Reinsurers (most of them European) were financially responsible for the bulk of these losses. These reinsurance payments came in the wake of outlays triggered by a series of catastrophic natural disasters over the past decade and portfolio losses due to stock market declines. Having their capital base severely hit, most reinsurers decided to reduce their terrorism coverage drastically or even to stop covering this risk.

Hence, in the immediate aftermath of September 11, 2001, U.S. insurers found themselves with significant amounts of terrorism exposure from their existing portfolio with limited possibilities of obtaining reinsurance to reduce the losses from a future attack. The few that did provide coverage to their clients charged very high prices. For example, prior to 9/11 the Chicago's O'Hare airport carried $\$ 750$ million of terrorism insurance at an annual premium of $\$ 125,000$; after the terrorist attacks, insurers only offered $\$ 150$ million of coverage at an annual premium of \$6.9 million (Jaffee and Russell, 2003).

\footnotetext{
${ }^{2}$ These payments are lower than the original $\$ 40$ billion estimate by the insurance industry (Hartwig, 2002). This is primarily because of lowered liability expectations and greater utilization of the federal Victim Compensation Fund that will have paid nearly $\$ 5$ billion to $9 / 11$ victims and their family (Smetters, 2004). It is worth noting that the fund requires the beneficiaries to relinquish their rights to going to court, thus limiting liability losses that might otherwise have ended up in court and possibly paid by the insurance industry.
} 
Insurers warned that another event of comparable magnitude could do irreparable damage to the industry. ${ }^{3}$ Furthermore, they contended that the uncertainties surrounding large-scale terrorism risk were so significant that it was, in fact, an uninsurable risk. In October 2001, the Insurance Services Office, on behalf of insurance companies, filed a request in every state for permission to exclude terrorism from all commercial insurance coverage (U.S. General Accounting Office, 2002). By early 2002, 45 states permitted insurance companies to exclude terrorism from their policies, except for workers' compensation insurance policies that cover occupational injuries without regard to the peril that caused the injury (U.S. Congress Joint Economic Committee, 2002). With that exception, by September 11, 2002, very few firms had other insurance coverage against a terrorist attack (Hale, 2002).

This situation led to a call from some private sector groups for federal intervention. For example, the construction and real estate industries claimed that the lack of available terrorism coverage delayed or prevented several projects from going forward due to concerns by lenders or investors (U.S. General Accounting Office, 2002). In response to these concerns the Terrorism Risk Insurance Act of 2002 (U.S. Congress, 2002), based on risk sharing between the insurance industry and federal government, was passed by Congress on November 26, 2002 and signed into law by President Bush. However, the act expires on December 31, 2005, and it is unclear what type of terrorism insurance program, if any, will emerge in the United States. ${ }^{4}$

\footnotetext{
${ }^{3}$ For an empirical study of the market reactions to 9/11, see Doherty et al. (2003).

${ }^{4}$ Three bills to extend the Terrorism Risk Insurance Act (TRIA) program for an additional two to three years beyond 2005 were introduced during the summer of 2004: the House Democrats' bill (H.R. 4772), House Republican bill (H.R. 4634) and the bipartisan Senate bill (S. 2764). The House Financial Services Committee approved H.R. 4634 in late September. For a discussion of potential economic effects of TRIA's expiration, see Hubbard and Deal (2004).
} 


\section{The Terrorism Risk Insurance Act of 2002: A Temporary Answer}

Under the Terrorism Risk Insurance Act of 2002, insurers are obligated to make available an insurance policy against terrorism to all their clients. The coverage limits and deductibles must be identical to non-terrorism coverage, but TRIA does not provide any guidance as to what rates should be charged. The insured can decline the offer. If the U.S. Treasury Secretary certifies an event as an "act of terrorism" carried out by foreign persons or interests ${ }^{5}$ and involving losses in excess of $\$ 5$ million, then losses would be shared between federal government and insurers.

There are two layers associated with TRIA reflecting who is financially responsible for the losses from a terrorist event. The insurers retain the first layer through a deductible provision, determined as a percentage of the direct commercial property and casualty earned premiums of each insurer the preceding year: 10 percent in 2004 and 15 percent in 2005. The deductible level can be large; for example, AIG's 2004 deductible has been estimated to be $\$ 2.7$ billion, others like Travelers, ACE, Chubb or Berkshire have lower 2004 deductibles: $\$ 928$ million, $\$ 743$ million, $\$ 600$ million and \$200 million, respectively (Morgan Stanley, 2004). The federal government and insurers are jointly responsible for the second layer of insurance industry losses up to $\$ 100$ billion. Specifically, the government pays 90 percent of each insurer's primary property-casualty losses during a given year above the applicable insurer deductible and the insurer covers the remaining 10 percent. Should the insurance industry's losses exceed $\$ 100$ billion during a given year, then the U.S. Treasury determines how the losses will be divided between insurers and the federal government.

\footnotetext{
${ }^{5}$ A domestic terrorist event like the Oklahoma City bombings of 1995, had been the most damaging terrorist attack on domestic soil before September 11, 2001 is not covered under TRIA. There were 168 people killed and losses were inflicted mostly to federal property and employees. TRIA does not cover life insurance either. The risks related to a terrorist attack using chemical, biological, radiological and nuclear weapons of mass-destruction are covered under TRIA only if the primary insurer has included these risks in its standard commercial policy.
} 
If the insurance industry suffers terrorism losses that require the government to cover part of the claims payments, then these outlays are partially recouped after the event by the U.S. Treasury through a mandatory policy surcharge levied against insurers. Insurers, in turn, can impose a surcharge on all property and casualty insurance policies, whether or not the insured has purchased terrorism coverage. Should the final payments by the insurance industry in any given year exceed a certain level ( $\$ 15$ billion for 2005), the federal government would pay for the losses above this amount without the possibility of recouping such payments.

It is worth noting that the federal government does not receive any premium for providing this coverage. Reinsurers cannot compete with this implicit zero cost federal terrorism reinsurance program and their role has been limited to covering the deductible and the 10 percent share of insurer's potential liability (15 percent in 2005).

TRIA requires private firms to offer terrorism insurance but also seeks to ease insurers concerns about suffering large losses from future terrorist events. The intent of the Act was that insurers would offer terrorism coverage at premiums that would be attractive to firms at risk who would then decide to purchase it. Although there has been an increase of demand for terrorism insurance in recent months, there is no guarantee that firms will continue to purchase coverage in the future. The latest information suggests a majority of firms have not purchased terrorism insurance early in $2004 .^{6}$ Should another large-scale terrorist attack occur soon, many firms would be unprotected and insurers are likely to rethink their role yet again (MacDonald, 2004).

\footnotetext{
${ }^{6}$ Data compiled by Marsh Inc. (2004) from more than 800 businesses and government entities that renewed property insurance policies in the second quarter of 2004 revealed that 46 percent of them had bought terrorism insurance compared to 44 percent in the first quarter of 2004 and 32 percent in the fourth quarter of 2003 . The following two factors appear to explain this increase in demand: Recent alerts released by the federal government on possible attacks in the United States have increased firms' concern with terrorism. Since the overall pricing for commercial property insurance has continued to decrease, firms have freed up funds to purchase terrorism insurance coverage.
} 


\section{Distinctive Challenges of Terrorism Insurance}

In the field of risk management and insurance, terrorism presents a set of very specific challenges. First, there is the potential for extremely large losses due to changes in the nature of terrorism over the past decade. Today there are an increasing number of religious-based terrorist groups, many of whom advocate mass casualties (Hoffman, 1998; Stern, 2003; Sandler and Enders, 2004). ${ }^{7}$

Second, insurers have a difficult time pricing terrorism insurance given the uncertainty associated with the risk. Although terrorism risk models have been developed in the past two years, they are primarily designed to specify insurer's potential exposure to losses from a wide range of scenarios characterizing the attack (Kunreuther, Michel-Kerjan and Porter, in press). The models are not well-suited in estimating the likelihood of any of these scenarios occurring. In contrast to other catastrophic risks such as natural hazards, where large historical databases and scientific studies on the risks are in the public domain, data on terrorist groups' activities and current threats are normally kept secret by federal agencies for national security reasons. For example, the public still has no idea today who manufactured and disseminated anthrax in U.S. mailings during autumn 2001. Without this information, it is difficult for modelers to make projections as to the capability and opportunities of terrorists to undertake similar attacks or disruptive actions in the future.

Third, the risk of future terrorist attacks depends on the terrorists' will to attack and their chosen modes. Their strategies may be partially determined by the protective measures undertaken by those at risk and on actions taken by the government to enhance general security. Moreover, foreign policy decisions made by a government can deeply affect the desire of terrorist groups to

\footnotetext{
${ }^{7}$ Large-scale terrorist attacks against civilians in Madrid, Spain on March 11, 2004, have been credited with altering the outcome of the Spanish election that occurred three days later, and hence raises the question as to the potential impact of terrorism as a global political weapon.
} 
attack a certain country or its interests abroad (Lapan and Sandler, 1988; Lee, 1988; Pillar, 2001) This point was underscored by the 9/11 Commission Report on terrorist attacks (National Commission, 2004). In this sense, terrorism risk depends on actions by both the private and public sectors and is continuously evolving. This makes the risk of future terrorist events extremely difficult to estimate.

A fourth challenge arises in pricing terrorism risk insurance due to the existence of interdependencies. In contrast to other insurance, where premium reductions are given to policyholders who undertake preventive measures (like making buildings safer against fire), an insurer on its own may not be in a position to offer this type of economic incentive for terrorism coverage because of the interconnectedness between firms with respect to this risk. The vulnerability of one organization, critical economic sector or country depends not only on its own choice of security investments, but also on the actions of other agents. Failures of a weak link in an interdependent system can have devastating impacts on all parts of the system.

Interdependencies do not require proximity, so the antecedents to catastrophes can be quite distinct and distant from the actual disaster. In the case of the 9/11 attacks, security failures at Boston's Logan airport led to crashes at the World Trade Center (WTC), the Pentagon, and in rural Pennsylvania. The same was true of the crash of PanAm103 over Lockerbie, Scotland in December 1988. The disaster was caused by a bomb in a suitcase loaded at Goso Airport, Malta on Malta Airlines where security measures were lax. The suitcase was then transferred to a Pan Am feeder in Frankfort, and then onto Pan Am 103 in London set to explode only if the plane flew over 28,000 feet, a height normally first attained on this route over the Atlantic Ocean (Lockerbie, 2001).

Such interdependencies may lead to a situation where all or many firms decide not to invest in protection because they know that the failure of others to take similar actions can affect them even 
if they exert care themselves. In theory, a social insurance program can institute regulations and standards to reduce these negative externalities to achieve a socially optimal level of investment in protection, but it may not be so easy to implement these measures. (Kunreuther and Heal, 2003; Heal and Kunreuther, in press).

Crisis management in the aftermath of an attack also can have huge impacts and ripple effects. Actually, the 9/11 events, as well as the anthrax attacks, demonstrated a new kind of vulnerability: terrorists can use the capacity of a country's critical infrastructure to have a large-scale impact on the nation by turning the diffusion capacity of our own networks against ourselves. Each element of the network -- every aircraft, every piece of mail -- can thus become a potential weapon endangering the entire network (Michel-Kerjan, 2003a). Another limitation of terrorism insurance is that it normally does not cover losses unless the insured is the direct target of an attack (Godard et al., 2002). For example, following the terrorist attacks of 9/11 the Federal Aviation Administration (FAA) banned takeoffs of all civilian aircraft regardless of destination. In March 2004, the city of Chicago was denied insurance compensation for business interruption losses that resulted from the FAA's decision. The specific clause of the insurance contract for business interruption specified covering only "direct result of a peril not excluded," thus imposing a territorial limitation that excludes interdependent effects due to the response to an attack (U.S. District Court, 2004).

\section{Developing a Sustainable Terrorism Insurance Program}

Congress requires that the U.S. Department of the Treasury assess the effectiveness of TRIA no later than June 30,2005 , to determine whether it should be renewed, whether an alternative terrorism insurance program should be substituted for it, or whether insurance coverage should be 
left in the hands of the private sector. As input into this process, we now consider several alternative terrorism insurance programs and scenarios.

\section{A Market Approach}

In this scenario, the Terrorism Risk Insurance Act of 2002 would expire and a private market for terrorism insurance would be allowed to operate without any federal backstop or mandatory offer requirement. Some economists contend that the private market has the capacity to develop a market for covering terrorism risks and that government intervention limits the development of private solutions (Gron and Sykes, 2002; Jaffee and Russell, 2003). Others argue that certain changes in tax, accounting and regulation would make it less costly for insurers to hold surplus capital and allow prices to adjust freely. Private insurers would then be more likely to cover the terrorism risk adequately (Smetters, 2004). To date no serious legislative efforts have been undertaken to initiate such changes.

Should the federal government withdraw its financial support, most private insurers are likely to offer terrorism insurance only if they can protect themselves against catastrophic losses by purchasing reinsurance or through securitization of risks via innovative mechanisms like catastrophe bonds. A catastrophe bond transfers the risk of a large loss from the insurance/reinsurance industry to the financial markets. It has the following structure: under explicit conditions specified at its issuance the bond pays a higher than normal interest rate, but the interest and/or principal payments will be lost if a catastrophe occurs.

Neither of these risk transfer mechanisms seems especially promising. Even with TRIA in place, reinsurers have only cautiously returned to terrorism insurance, but most insurers have not

purchased reinsurance probably due to the relatively high premiums for a limited amount of available coverage (U.S. GAO, 2004). Catastrophe bonds have been used since 1996 to cover the 
risk of large losses from some natural disasters, but a sustainable market for catastrophe bonds to cover losses from terrorist attacks has not emerged since 9/11. It is not clear whether the situation will change in the near future, at least in the United States (Kunreuther and Michel-Kerjan, forthcoming; U.S. GAO, 2003). ${ }^{8}$

In fact, to date there has been little movement and coordination between insurers and reinsurers toward developing a private-industry program that could provide sufficient capacity without government participation (U.S. GAO, 2004). If nothing is done after TRIA expires, insurers will probably significantly increase the price of coverage, since free federal reinsurance will no longer be available. Many insurers may even decide not to offer this coverage to their clients, as they would no longer be required to do so by law. On the demand side, many firms are likely to conclude, as memories of $9 / 11$ fade, that such insurance is too costly and not strictly necessary. The risk of future losses will be viewed as below their threshold level of concern. Moreover, if firms know that other firms have also not purchased coverage, they are likely to believe that the federal government will assist them following a terrorist attack. For these reasons, few businesses are likely to be financially protected against the risks of terrorism.

This outcome may be considered efficient until after the next terrorist attack, when providing adequate financial protection to victims of catastrophes will again take center stage. Under public pressure, it could be politically difficult for the government not to compensate the uninsured for damage they sustain. Due to the uncertainty of the risk and the fear of future catastrophic losses,

\footnotetext{
${ }^{8}$ The first terrorism-related catastrophe bond was issued in Europe in August 2003. The world governing organization of association football (soccer), the FIFA, which organizes the 2006 World Cup in Germany, developed a bond to protect its investment should either a natural disaster or a terrorist attack occur that would result in the cancellation of the final World Cup game without the possibility of it being re-scheduled to 2007. The second terrorist-related bond is a securitization of catastrophe mortality risk undertaken in 2003 by Swiss Re, the world's largest life reinsurer. (Woo, 2004).
} 
many insurers would likely withdraw temporarily from the market as they did right after $9 / 11$. Under such a scenario, new legislation is likely to impose legal requirements for terrorism insurance.

This cycle is common in the aftermath of a catastrophic natural disaster. Following Hurricane Andrew in 1992 that inflicted \$20 billion of insured losses (measured in 2002 dollars), insurers were prepared to cancel windstorm coverage in hurricane-prone areas of Florida. The state legislature passed a law the next year that individual insurers could not cancel more than 10 percent of their homeowners' policies in any county in any one year and that they could not cancel more than 5 percent of their property owners' policies statewide. At the same time, the Florida Hurricane Catastrophe Fund was created to relieve pressure on insurers should there be a catastrophic loss from a future disaster (Lecomte and Gahagan, 1998). In California, insurers refused to renew homeowners' earthquake policies after the 1994 Northridge earthquake that caused \$17 billion of insured losses (in 2002 dollars). This led to the formation in 1996 of a state-run earthquake insurance company, the California Earthquake Authority, with funds for its operation provided by insurers and reinsurers (Roth, 1998).

\section{Mutual Insurance Pools}

Under this arrangement insurers would be allowed to form an insurance pool to deal with specific lines of coverage. In effect, a group of companies provides reinsurance to each other. This solution has the advantage of spreading the risk over a large number of insurers who join these pools, but it is unclear whether this alternative would provide adequate coverage against megaterrorism. A group of 14 U.S. workers' compensation insurers that accounts for roughly 40 percent of the market assessed the feasibility of a workers' compensation terrorism reinsurance pool, since terrorism protection cannot be excluded from workers' compensation coverage (Towers Perrin, 2004). The feasibility study concluded that while the pool could create some additional capacity for 
each of its members, it would not be enough to matter in the case of a large-scale terrorism attack. The report stated that extreme terrorist attacks could inflict workers' compensation losses of $\$ 90$ billion, three times the capital backing of the private industry's capacity for covering this line of business. In addition, the report concluded that it would be difficult to reach an agreement on the rates that should be charged based on terrorism exposure of pool participants.

There are challenges associated with the creation and operation of a pool arrangement. Should it hold funds before a terrorist attack, or should it be an arrangement to supply such funds after an attack? Should participation in the pool be voluntary or mandatory? To what extent could the pool diversify risk and create additional capacity for each of its members? What rating scale should be charged by the pool to each of its members, and how could one reach a consensus by those considering joining? What would be the relationship between premiums charged by primary insurers to policyholders and those charged by the pool to cover each member insurer?

There are data available to address these questions. For example, potential losses associated with a large range of scenarios of attacks are better understood today. Terrorism risk models developed since September 11 could be used to establish a national scale of rates charged by the pool based on terrorism exposure (Kunreuther, Michel-Kerjan and Porter, in press). There are also lessons to be learned as to how rates charged by pools established in other countries have been defined. It is also worth understanding why specific programs abroad were created or modified after 9/11 and how they work in practice (Michel-Kerjan, 2003b; Partner Re, 2004). For example, France, Germany and the United Kingdom, along with other European countries and Australia, have all developed insurance programs based on a pool of insurance/reinsurance with a back-up by the government. Each government, in collaboration with representatives of the insurance industry, sets up national scale of reinsurance rates charged by the pool that depend on location of the risk (Pool 
Re in the United Kingdom) or on total insured value wherever the risk is located (Gareat in France, Extremus in the Germany) (Michel-Kerjan and Pedell, forthcoming).

If a pool arrangement is to emerge in the United States as part of an overall package for providing terrorism insurance, it seems likely that national associations of insurers and reinsurers, in partnership with the U.S. Treasury, could play a key role in its implementation and in undertaking systematic analyses as to how well the system is actually working.

\section{Layers of Insurance}

The challenge in providing terrorism insurance is to spread the risks appropriately between the insured parties, the insurance industry, broader capital markets, and the government. Here we sketch a proposal to provide terrorism coverage through a multi-layer system.

Those purchasing terrorism insurance would be responsible for the initial level of losses through a deductible on the policy. It might be possible to have an arrangement in which the size of the deductible and the premium were based to some extent on the nature of loss reduction measures and response preparedness in which the insured would have invested.

For losses above the deductible, insurers and reinsurers would cover a second tier of losses up to a specific threshold for total losses. One option could be the creation of a pool arrangement similar to current programs in European countries. Since a pool arrangement brings insurers together, it might encourage them to link coverage with risk mitigation/response preparedness measures so as to deal explicitly with the negative externalities caused by the interdependencies associated with terrorism risk discussed above. For example, all insurers in the pool may want to require specific risk reduction measures as a condition for coverage. They may also want to negotiate a specific arrangement with the public sector for reimbursement of business interruption 
losses resulting from federal responses to an attack, such as shutting down the airlines, the postal system or other critical infrastructure.

There could be a pre-existing arrangement for the pool to obtain federal loans at low rates, should the reserves of the pool be insufficient during its first years of operation to cover insurance losses from a major attack. If the pool's financial commitment is well-defined and limited to a specified amount of coverage, a consortium of international insurers and reinsurers could cover a specific range of losses above the pool's liability, as has been done by Swiss Re in France or Berkshire Hathaway in Germany (Michel-Kerjan and Pedell, forthcoming). If reinsurers are willing to provide substantial amounts of coverage, then investors might want to provide capital for issuing terrorism catastrophe bonds.

State and federal reinsurance could cover losses for extreme events that exceeded the layers of private coverage. The public sector has the capacity to diversify the risks over the entire population and to spread past losses to future generations of taxpayers, a form of cross-time diversification that the private market cannot achieve because of the incompleteness of intergenerational private markets and legal limitations for insurers to accumulate financial reserves (Gollier, 2002; Smetters, 2004). Such government reinsurance protection could be provided with its charging insurance companies a premium based on how much coverage they would require to protect themselves against catastrophic losses from a terrorist attack. By tying the reinsurance premium to the amount of coverage, the government could provide an additional economic incentive for insurers to require all their policyholders to invest in specific protective measures.

\section{Required Insurance}

If terrorism insurance is voluntary, it seems likely that the combination of reluctant insurers and reluctant buyers will result in limited coverage. Banks could require terrorism insurance 
coverage as a condition for loans and mortgages to protect their own financial interests, as they do for fire coverage today. A broad move in this direction currently does not exist, although as pointed out above, pressure for TRIA was stimulated by a delay in projects due to the requirements by financial institutions to be covered against losses due to terrorism. (U.S. GAO, 2003). An alternative would be for government to require all firms to purchase terrorism insurance.

Mandatory coverage for terrorism risks would address many difficult problems. Since all firms would be financially protected, it would reduce the demand for government aid that is sure to arise after an attack by those who failed to purchase insurance. The recovery process would be facilitated through insurance claims dispersed rapidly to those suffering losses. By expanding the market for terrorism coverage, the insurance industry could diversify its risks across structures, industries and geographical areas, and stabilize premium incomes.

To date, the question as to whether coverage should be required has not been explicitly part of the debate regarding the future of terrorism insurance in the United States. It was discussed 50 years ago as part of a dialog on the creation of war damage insurance program in the aftermath of World War II (Hirshleifer, 1953). That question may be given serious consideration if other terrorist attacks, even small-sized ones, occur on U.S. soil. Indeed, the more an industrialized country has suffered from terrorism, the more likely such coverage has been made mandatory, as in France and Spain. Obviously, it is much easier to defend a voluntary private market approach for providing terrorism insurance when no losses have been incurred.

\section{Conclusion}

Insurance is a way of spreading risk and a way of encouraging investments in protective measures to reduce the likelihood and potential losses from a future untoward event. It also 
contributes to the social and economic continuity of the country should a large-scale terrorist attack occur. In the aftermath of September 11, 2001, the insured costs associated with the terrorist attacks were spread across the U.S. and European economies. There were debates here and abroad on the role and responsibilities of the federal government and the private sector in providing adequate protection against terrorism. In the United States, this led to the passage of the Terrorism Risk Insurance Act of 2002 (TRIA).

Broadly understood, how we approach the issue of terrorism risk insurance is an important tile within the mosaic of our national security. Today the development of a public-private partnership could facilitate the creation of a large and sustainable insurance market for terrorism risk. The U.S. government could partner more systematically with the private sector, not only in providing some degree of government reinsurance, but also in facilitating private sector insurance arrangements. Such an involvement of the public sector would also facilitate the linkage of terrorism insurance with private expenditures to better prepare the nation by reducing interdependent risks of terrorism and hence the direct and indirect consequences of an attack.

We believe, however, that there are better ways to deal with these financial issues than through TRIA. If a two year extension of TRIA is approved, Congress could explicitly request a study involving the affected stakeholders for developing such a sustainable terrorism insurance program in the United States. We also are concerned that if nothing coherent is done should TRIA expire, another terrorist mega-attack could have a much greater financial and social impacts than what the nation experienced after $9 / 11$.

\section{REFERENCES}


Doherty, Neil, Lamm-Tennant, Joan, and Starks, Laura. 2003. "Insuring September 11th: Market Recovery and Transparency". Journal of Risk and Uncertainty. 26:2/3, pp. 179-199.

Godard, Olivier, Henry, Claude, Lagadec, Patrick and Erwann Michel-Kerjan. 2002. Treatise on New Risks. Precaution, Crisis Management, Insurance. Paris: Editions Gallimard, FolioActuel, p.620.

Gollier, Christian. 2002. "Insurability". Paper presented at the NBER Insurance Group Workshop. Cambridge. MA, February 1.

Gron, Anne and Sykes, Alan. 2002. "Terrorism and Insurance Markets: A Role for the Government as Insurer?" Regulation. Winter 2002-2003, pp.44-51.

Hale, David. (2002). “America Uncovered.” Financial Times. September 12.

Hartwig, Robert. 2004. “The Fate of TRIA: Is Terrorism an Insurance Risk?” Insurance Information Institute, New York, NY.

Hartwig, Robert. 2002. "September 11, 2001: The First Year. One Hundred Minutes of Terror that Changed the Global Insurance Industry Forever." Insurance Information Institute, New York, NY.

Heal, Geoffrey and Kunreuther, Howard. (in press). "IDS Models of Airline Security" Journal of Conflict Resolution.

Hirshleifer, Jack. 1953. “War Damage Insurance.” Review of Economics and Statistics. 35: 2, pp.144-153.

Hoffman, Bruce. 1998. Inside Terrorism. New York: Columbia University Press.

Hubbard, Glenn and Deal, Bruce. 2004. "The Economic Effects of Federal Participation in Terrorism Risk.” Analysis Group. September 14.

Jaffee, Dwight and Russell, Thomas. 2003. "Market Under Stress: The Case of Extreme Event Insurance" in Richard Arnott, Bruce Greenwald, Ravi Kanbur and Barry Nalebuff (eds), Economics for an Imperfect World: Essays in Honor of Joseph E. Stiglitz. MIT Press.

Kunreuther, Howard and Michel-Kerjan, Erwann. (forthcoming). Insurability of (Mega)Terrorism. Challenges and Perspectives. Report for the OECD Task Force on Terrorism Insurance; revised version, September 2004. Paris: Organization for Economic Cooperation and Development.

Kunreuther, Howard, Michel-Kerjan, Erwann and Porter, Beverly. (in press). "Extending Catastrophe Modeling to Terrorism" in Patricia Grossi and Howard Kunreuther (eds.), with Chandu Patel. Catastrophe Modeling: A New Approach to Managing Risk. Kluwer Academic Publisher, Boston.

Kunreuther, Howard and Heal, Geoffrey. 2003. "Interdependent Security." Journal of Risk and Uncertainty. 26:2/3, pp. 231-249.

Lapan, Harvey and Sandler, Tood. 1988. "To Bargain or Not to Bargain: That is The Question". American Economic Review. 78:2, 16-20.

Lecomte, Eugene and Gahagan, Karen. 1998. "Hurricane Insurance Protection in Florida" in Kunreuther Howard and Roth, Richard, Sr. (eds.), Paying the Price: The Status and Role of Insurance Against Natural Disasters in the United States. Washington, D.C: Joseph Henry Press.

Lee, Dwight. 1988. "Free Riding and Paid Riding in the Fight Against Terrorism". American Economic Review. 78:2, pp. 22-26.

Lockerbie, Verdict. 2001. Her Majesty's Advocate, v. Abdelbaset Ali Mohmed Al Megrahi and Al Amin Khalifa Fhimah, Case No.: 1475/99. High Court of Justiciary at Camp Zeist: January 31.

MacDonald, James. 2004. "Terrorism, Insurance, and TRIA: Are We Asking the Right Questions?" The John Liner Review.18:2, pp.87-96. 
Marsh Inc. 2004."Marketwatch: Property Terrorism Insurance. Update-2 ${ }^{\text {nd }}$ Quarter 2004”, August 2004.

Michel-Kerjan, Erwann and Pedell, Burkhard. (forthcoming) "Terrorism Risk Coverage in the Post-9/11 Era: A Comparison of New Public-Private Partnerships in France, Germany and the U.S." Geneva Papers on Risk and Insurance.

Michel-Kerjan, Erwann. 2003-b. "Large-scale Terrorism: Risk Sharing and Public Policy." Revue d'Economie Politique. 113:5, pp. 625-648.

Michel-Kerjan, Erwann. 2003-a. "New Vulnerabilities in Critical Infrastructures: A U.S. Perspective." Journal of Contingencies and Crisis Management. 11:3, pp.132-141.

Morgan Stanley. 2004. “Assessing Insurer's Terrorism Risk”. Equity Research, Insurance Property and Casualty, March.

National Commission on Terrorist Attacks Upon The United States. 2004. The 9/11 Commission Report. Washington, DC., July.

Partner Re. 2004. "Terrorism Insurance. Pools \& Market Solutions in Europe”, May.

Pillar, Paul. 2001. Terrorism and U.S. Foreign Policy. Washington, DC: Brookings Institution Press, p272.

Roth, Richard, Jr. 1998. "Earthquake Insurance Protection in California" in Kunreuther Howard and Roth, Richard, Sr. (eds.), Paying the Price: The Status and Role of Insurance Against Natural Disasters in the United States. Washington, D.C: Joseph Henry Press.

Sandler, Todd and Enders, Walter. 2004. "An Economic Perspective of Transnational Terrorism”, European Journal of Political Economy. 20:2, pp.301-316

Smetters, Kent. 2004. "Insuring Against Terrorism: The Policy Challenge". Brookings-Wharton Papers on Financial Services, Robert E. Litan and Richard Herring (eds.), pp. 139 - 182.

Stern, Jessica. 2003. Terror in the Name of God: Why Religious Militants Kill. New York: Harper Collins.

Towers Perrin. 2004. "Workers' Compensation Terrorism Reinsurance Pool Feasibility Study". March.

U.S. Congress. 2002. Terrorism Risk Insurance Act of 2002. HR 3210. Washington, DC., November 26.

U.S. Congress, Joint Economic Committee. 2002. Economic Perspectives on Terrorism Insurance. Washington, DC: May 2002.

U.S. District Court for the Northern District of Illinois, Eastern Division. 2004. City of Chicago v. Factory Mutual Insurance Company. 02C7023. March 11.

U.S. General Accounting Office (GAO). 2004. Terrorism Insurance. Effects of the Terrorism Risk Insurance Act of 2002. Testimony of Richard Hillman. GAO-04-720T. Washington, D.C.: April 28.

U.S. General Accounting Office (GAO). 2003. Catastrophe Insurance Risks. Status of Efforts to Securitize Natural Catastrophe and Terrorism Risk. GAO-03-1033. Washington, D.C.: September.

U.S. General Accounting Office (GAO). 2002. “Terrorism Insurance: Rising Uninsured Exposure to Attacks Heightens Potential Economic Vulnerabilities." Testimony of Richard J. Hillman before the Subcommittee on Oversight and Investigations, Committee on Financial Services, House of Representatives. February 27.

White House. 2002. National Strategy for Homeland Security. Washington, DC, July 2002.

Woo, Gordon. 2004. "A Catastrophe Bond Niche: Multiple Event Risk", Paper presented at the NBER Insurance Group Workshop, Cambridge, MA, February 7. 
